УДК 94:276.2](47+57)»1860/1923»

DOI $10 / 15421 / 312004$

Е. Е. Ходченко

Днипровский начиональный университет имени Олеся Гончара

\title{
ИЗМЕНЕНИЕ МИРОВОЗЗРЕНИЯ РОССИЙСКИХ МЕННОНИТОВ И РАЗРУШЕНИЕ ИХ СООБЩЕСТВА
}

Ходченко Е. Е. Изменение мировоззения российских меннонитов и разрушение их сообщества. В статье рассматриваются вопросы рефлексии меннонитским сообществом на вызовов реформ в России, модернизации общественного, политического и экономического пространства в 1861-1914 гт., во время Первой мировой войны, смены властей и анархии в Украине в период гражданской войны. Автор рассматривает попытки меннонитов приспособиться к изменениям действительности, причинно-следственные связи кризисных социальных явлений, приведших в итоге к разрушению канонических основ этнорелигиозного сообщества.

Ключевые слова: меннониты, Первая мировая война, гражданская война, Махно, идентичность.

Ходченко О. Є. Зміна світогляду російських менонітів та руйнування Ix спільноти. У статті розглянуто питання рефлексії менонітською спільнотою викликів реформ у Росії, модернізації громадського, політичного і економічного простору в 1861-1914 pp., під час Першої світової війни, зміни влади і анархії в Україні в період громадянської війни. Автор розглядає спроби менонітів пристосуватися до змін дійсності, причинно-наслідкові зв'язки кризових соціальних явищ, що призвели у підсумку до руйнування канонічних основ етнорелігійної спільноти.

Ключові слова: меноніти, Перша світова війна, громадянська війна, Махно, ідентичність.

Khodchenko E. E. Verănderung des Weltbildes der russischen Mennoniten und Zerstőrung ihrer Gemeinschaft.

Der Artikel untersucht die Fragen der Reflexion der mennonitischen Gemeinschaft über die Herausforderungen der Reformen in Russland, die Modernisierung des sozialen, politischen und wirtschaftlichen Raums im den Jahren 1861-1914 während des Ersten Weltkriegs, den Machtwechsel und die Anarchie in der Ukrame während des Bürgerkriegs. Der Autor betrachtet die Versuche der Mennoniten, sich an Veränderungen im der Realität anzupassen, die Ursache-Wirkungs-Zusammenhänge von sozialen Krisenphänomenen, die letztendlich zur Zerstörung der kanonischen Grundlagen der ethnisch-religiösen Gemeinschaft führten.

Schlüsselwörter: Mennoniten, Erster Weltkrieg, Bürgerkrieg, Makhno, Identität.

Khodchenko E. E. Changing of the Russian Mennonites' outlook and the destruction of their community.

The article raises the problems of the Mennonite community's reflection on the reforms in Russian Empire as well as the modernization of social, political and economic environment in 1861-1914, during the First World War, the recurring power changes and political anarchy in Ukraine during the Civil War. The author examines the Mennonites' attempts to adjust the changes im reality, the cause-and-effect relationships of arising social crisis which ultimately led to the destruction of the ethnoreligious community's canonical foundations. The research bases on the testimomies of the eyewitnesses (given im their diaries), memoirs and other published materials. The author exammes the gradual deviation processes among the Mennonite society that were transforming the fundamental statements of the congregations' doctrine and their moral norms and traditions. It is analyzed whether the Russian-Ukrainian Mennonites remained an ethno-religious conglomerate or lost their inherent values. As a result it has been proved the following: the Mennonites $\mathrm{m}$ Russia in a short period from the beginning of the reforms of the 1860s 1870 s to the beginning of the $20^{\text {th }}$ century, went from a close-knit religious community to an opened and spiritually weakened unification. During the period of "challenges and reactions" of the First World War and the Civil War, the leaders of the community were unable to maintain the unity and cohesion, a complex of moral and ethical markers, pacifist views, social institutions, which led to a deformation of values and disorientation in further actions. Only a

(C) Е. Е. Ходченко, 2020 
small part of the Mennonites society was able to organize itself and, thanks to the support of the Canadian Mennonites communities, it emigrated in 1923-1926 and thus avoided the Bolshevik regime repressions.

Key words: the Mennonites, World War I, Civil War, Makhno, identity.

«Во веки останется знаменательным то, что со времени Реформации существует церковная община, которую можно назвать воплощенным воспоминанием об идеале Царства Божьего». С. Н. Wedel [24]

Проблема исследования. Каждый народ на протяжении веков вырабатывает и несет в себе характерные этнокультурные черты, соединяющие его в единое целое, и часто политическую субъективность. Меннониты, прибыв в Российскую империю из германских земель-государств, где они жили столетиями, обладали рядом отличительных от немцев признаков, определяющих их этнорелигиозную идентичность и объединяющих в особое сообщество. Эти уникальные нравственно-религиозные маркеры они старались сохранить и в России. Однако в моменты исторических потрясений перед ними встали нелегкие вопросы выбора пути - оставаться верными вере и традициям предков, принять одну из политических сторон или приспособиться к анархическому безвластию. Неправильный выбор грозил разрушением сообщества.

Цель работы - опираясь на свидетельства участников событий, приведенных в их дневниках, мемуарах и опубликованных материалах, проследить поэтапные отступления меннонитов от фундаментальных основ своего вероучения, норм морали и традиций, а также определить, остались ли меннониты, проживавшие на территории юга Украины, религиозно-пацифистским сообществом.

Актуальность темы. Источники и историография. В последние десятилетия в работах зарубежных и отечественных историков все чаще поднимаются вопросы этнопсихологии в историческом контексте. Авторы данного направления предметом своего поиска ставят «внутреннее восприятие событий прошлого" посредством свидетельств отдельных индивидуумов, социальных кластеров, общности / народа / нации в целом. Этот подход позволяет воссоздать «картину событий» изнутри, наполнить историю эмоциями и переживаниями.

Многие канадские, американские, украинские, российские исследователи предметно изучают историю этноконфессиональной группы меннонитов. Вопросами изменения идентичности данного религиозного сообщества занимались: Н. В. Венгер, которая выделяет период гражданской войны для меннонитов как период «безвременья» [2], И. Дик, выдвинувший тезис о процессе секуляризации идентичности меннонитов в начале XX в. [4], X. Вернер, представивший противоречия этнонациональной идентичности в период развала имперской власти в России [25], Дж. Тевс, образно отразивший трагизм событий в Блюменорте в 1919 г. [21]. Такой исследовательский интерес к меннонитам обусловлен тем, что данная этноконфессиональная группа, опираясь на традиционные религиозно-этические ценности, смогла на протяжении своей истории приспособиться / адаптироваться / выжить, оставить не только память о себе, но и привнести весомый вклад в развитие мировой пацифистской идеологии. Актуальность темы неразрывно связана с вопросами рефлексии обществом / общественным сознанием политических процессов, происходящих в государстве.

В понимании религиозно-политической элиты меннонитов XIX в. реформы государственного управления в России 60-70-х годов стали угрозой их вере, моральным принципам, традициям и образу жизни. Поэтому с 1874 по 1878 г. 18000 наиболее консервативных членов сообщества покинули империю и переселились на американский континент. Оставшиеся пошли на компромисс с государством по главному мировоззренческому вопросу в части выполнения альтернативной службы вместо воинской строевой, при этом сохранив остальные признаки своей самобытности: автономность церкви, язык общения, религиозное воспитание и обучение молодежи в рамках меннонитских канонов, неслужение в государственных учреждениях. К числу приоритетов также относились: обособленность поселений, социально справедливое обеспечение членов сообщества, ответственность всех за каждого, поведенческие запреты, в том числе к запретам относились такие отступления от кодекса морали, как приведение к присяте, клятва, табакокурение, пьянство, светская музыка, танцы, адюльтер и др. Не одобрялось и неравномерное личное обогащение, поскольку в общинах действовал линейный налог (от стоимости имущества) для обеспечения общественных нужд.

Между тем реформы в России открыли новые экономические перспективы, чем бы- 
стро и эффективно воспользовались наиболее предприимчивые представители группы, создавая в колониях предприятия, выпускающие высоколиквидную продукцию (часто отсутствие земли и заставляло беднейших заниматься предпринимательством) или скупая плодородную землю. Растущие мирские интересы открыли замкнутое доселе сообщество к коммуникачии с иироким обществом, что одновременно, существенно ослабило его крайнюю религиозность. В течение достаточно короткого времени меннониты прошли путь от духовного закрытого сообщества к представлению о себе как о высшей по культуре и деловым качествам общности, способной занять лидерские позиции в предпринимательстве и землепользовании российского делового общества. Соответственно поменялись и ценностные ориентиры с духовных на прагматично-материалистичные, а внутри общности экономические интересы стали превалировать над обязательствами сочиальной справедливости и общественной ответственности.

К началу Первой мировой войны сообщество меннонитов было уже серьезно дифференцировано по имущественному признаку. Среди разбогатевших выделялась группа лиц, прочно связанная с промышленным производством, члены которой, являясь землевладельцами, не порывали связи со своими общинами. Они раньше других отказались от аскетического образа жизни, принятого в XVII в. (Леппы, Копы, Вальман, Нибуры, Нойфельды и др.). Представители этой группы, изменив моральным принципам, вошли в политику, властные и судебные структуры государства: Иван Эзау занимал должность городского главы Екатеринослава, Генрих Эдигер - Бердянска, Иоганн Янцен - города Орехов, Иоганн Тиссен - судьи, Якоб Гёзе и Корней Унру - судебных присяжных-поверенных, Генрих Ремпель выполнял обязанности члена суда волости [5], Герман Бергман и Петр Шредер являлись депутатами российской Государственной думы. Отступления от кодекса меннонитских идеалов стали первыми предвестниками кризиса и тревожили некоторых членов сообщества [3]. Однако на первоначальном этапе, в результате воспитания и функционирования отлаженных социальных программ, антагонизма в колониях не наблюдалось, а отступление от кодекса официально не порицалось.

Та часть меннонитов, которые несли альтернативную военную службу в лесных командах, до войны жили в маленьких лагерях, располагавшихся вблизи родных посе- лений, имели отлаженный быт, свое управление и проповедников. В их мир практически не проникали идеи, волнующие широкое российское общество. Поэтому отслужив, они легко возвращались к жизни в колониях.

Война изменила многое. Меннонитам пришлось во всеуслышание, в том числе на страницах своих газет, принести клятву верности царю и Русскому отечеству, что ранее не мыслилось. Кроме того, более 12 тыс. молодых мужчин (в десять раз больше, чем в мирное время) - добровольцев и призванных - оказались в бурлящих эмоциями реалиях войны. Служа санитарами, они увидели устрашающие картины, вызвавшие стресс у молодых людей [15]. Так, Николай Ремпель (доброволец из Мариенталя (Mariental) записался в санитары 24 июля 1914 г. [16]) в письме к жене писал: «Грузовой поезд с фронта только что подошел и стал рядом с нашим санитарным. Около тысячи раненных лежали в грязных грузовых вагонах, ужасно переполненных. Было холодно. Бедняги разжигали костры прямо на полу не обращая внимания на дым, который заполнял вагон - они просто хотели тепла. Никаких кроватей не было. Пол был покрыт конским навозом. Четыре дня они ничего не ели. Когда мы дали хлеб, они пожирали его так жадно, как дикие животные. Я просто не мог себе представить такого» [16, p. 19]. Другой санитар, служивший в поезде № 195, пишет: «...Глядя на умирающих на наших руках..., на раненного с ужасной раной, я еле сдерживал слезы» [15]. Бывали случаи, когда раненых грузили непосредственно с поля боя с открытыми ранами. На поезд № 187 погрузили солдата с почти оторванными ягодицами. По-видимому, его не сразу подобрали с поля сражения: «От ран шло страшное зловоние... Зияли две серо-грязные громадные раны. Что-то в них копошилось... черви!.. Он не стонал, не жаловался, только скрипели стиснутые от страшной боли зубы» $[10$, c. 3$]$.

Насмотревшись на жестокие картины войны, многие меннониты-санитары начинали сомневаться в милосердии Бога. Экстремальные обстоятельства явились экзаменом, проверяющим силу их убеждений. Они начали осознавать, что до войны жили в «островном мире», не видя реальностей, окружающих их колонии. Из письма Николая Ремпеля жене: «Для многих будет полезно, если они покинут дом» $[16$, p. 19].

В русскоязычной среде меннониты быстро усовершенствовали свои знания русского языка, читали газеты, старались понять культуру России. Якоб Нойфельд вспоми- 
нал, что, бывая в Москве в перерывах между рейсами, вместе с Юлиусом Классеном ходили в оперу, Третьяковскую галерею, посещали службы в православной церкви $[19$, р. 17], чувствовали себя в центре событий, волнующих Россию.

В продолжение войны многие меннониты, выделявшиеся грамотностью и серьезным отношением к работе, были переведены из санитаров на административные должности в учреждения Красного Креста, Всероссийского земского союза и пр., в том числе в Москве, Петербурге, Екатеринославе [20, р. 102], где происходило аккумулирование недовольства от сбоев в работе государства, ухудшения положения в стране, а также различных взглядов, революционньх идей. Тем временем из колоний стали приходить вести об осложнении жизни, обысках, свертывании меннонитских сочиальных программ. Лидеры-меннониты, не сумевшие обеспечить стабильность жизни односельчан, теряли авторитет. Николай Ремпель писал: «В течение примерно трех лет мы, медики, наблюдали... с ужасом и отвращением, когда нас предавали и лгали те самые люди, к которым мы обращались как к нашим лидерам - те, кто говорил нам, когда нас призывали, - братья, выходите в радости. Мы позаботимся о ваших семьях. Они не будут иметь недостатка. Как постыдно они обманывали нас, когда это было возможно» [16, p. 21]. Мысли классовой антипатии овладевали не только санитарами, пребывающими на фронте $^{1}$, но и жителями колоний. Катерина Ремпель в ответе мужу пишет, что разделяет его отвращение к богатой меннонитской элите, владельцам недвижимости [16, p. 205]. Такие же чувства присутствуют и у Анны Берг $[13$, c. 3]. Как видим, именно элита (старшины, проповедники, землевладельцы) обвинялись в ухудшении жизненных условий. Николай Ремпель допускает и оправдывает их право отвоевать справедливость силой. Это прямо указывает на произошедшую трансформацию взглядов, изменение в самосознании, мировоззрении. Мысль о возможности взять в руки оружие допускали и другие меннониты. Вдали от фронта, в колониях, изменению взглядов в сообществе способствовало производство на заводах, принадлежащих меннонитам, продукции военного назначения (бомбометов, снарядов, гранат и др.) ${ }^{2}$, что прямо противоречило духовным ориентирам меннонитской церкви. Начал таять последний и главный пункт кодекса идеологии - верность пачифизму.

В 1917 г. сообщество меннонитов, разочарованное в справедливости российского царя и государства, приветствовало Февральскую революцию, отменившую дискриминационные законы и подарившую надежду в будущее. В то же время многие вернувшиеся с военной службы, сочувствовали социалистическим идеям ${ }^{3}$. Они, как и либерально настроенная интеллигенция, полагали, что меннонитское сообщество срочно нуждается в реформах и, прежде всего, в демократических преобразованиях, в свободных выборах сильных лидерах, способных гарантировать справедливые программы социального обеспечения и либерализацию в вопросах вероисповедания. Предложения бывших военнослужащих рассматривались в 1917 г. на Генеральной конференции в НейГальбштадте (Neuhalbstadt) в июне и на Конгрессе в Орлове (Orloff) в августе, но результаты этих консультаций к конструктивным практическим изменениям не привели. Более того, выявилось серьезное несовпадение взглядов у старшего и более либерального молодого поколения. На конференции в Лихтенау (Lichtenau) в 1918 г., проведенной в период постоянной смены власти и роста бандитизма, в ходе дискуссий перед сообществом показательно остро встал вопрос: покориться насилию и уповать на милосердие Бога или сопротивляться с оружием в руках за право, справедливость и порядок. Было принято компромиссное решение «воздержаться от навязывания соблюдения принципа несопротивления», т. е. фактически санкционировался личный выбор в вопросе применения оружия с целью обороны [20, р. 142]. Это было окончательным показателем кризиса сообщества, высший орган которого позволил отступиться от своего основного принyипа совести. Отказ от принципа «не убивать» означал отказ от существующей системы морали и ее неминуемое разрушение. Его последствия проявились в период оккупации украинской земли австро-немецкими войсками, когда часть меннонитов вместе с немецкими отрядами участвовала в столкновениях с украинскими крестьянами, занявшими зем-

\footnotetext{
${ }^{1}$ В лесных и дорожных командах во время войны меннониты также как и санитары были рассредоточены по России. Служили обычно небольшими группами и были под воздействием окружающего русского большинства.

${ }^{2}$ В общинах меннонитов Канады и СІША подобные действия считались недопустимыми [11].

${ }^{3}$ Анна Берг в дневнике отмечает, что «кастовая система стала изошреннее» и что лозунг социалистов о равенстве и братстве привлекателен для многих [13, с. 27].
} 
ли, ранее принадлежащие колонистам; в период гражданской войны в 1919-1921 гг., когда часть меннонитов решилась с оружием защищать свою собственность путем организации самообороны. На вопросе причин становления самообороны нужно остановиться подробнее.

Когда плотность населения на юге России возросла, земельные участки славянских сел вплотную приблизились к колониям меннонитов. Участились случаи воровства с полей и вытаптывание посевов скотом крестьян. В период революции 1905 г. началось воровство из усадеб и конокрадство. Меннониты довольно легко решили эту проблему, привлекая для охраны украинских казаков. Когда в 1917 г. Временное правительство выпустило из тюрем уголовников, воровство, в том числе солдатами-дезертирами, постепенно переросло в грабежи. Затем в январе 1918 г. мелкие отряды большевиков жесткими мерами отбирали провиант, деньги и ценности. В округе расплодились ночные мародеры, которые с каждым месяцем становились все более смелыми и дерзкими. Меннонитам пришлось увеличить количество ночных сторожей, вооружение которых первоначально составляли дубины. Порой по сигналу сторожей все мужское население колонии выбегало для охраны. Однако еще до прибытия немецких войск в Украину в некоторых колониях Молочанского округа несколько человек стали тайно использовать огнестрельное оружие. Первоначально старались соблюдать атмосферу секретности, так как многие строго придерживались своей веры. В течение короткого времени об оружии узнали все, в том числе проповедники, которые тоже пользовались защитой и, не проявив твердой позиции, молча одобрили меры насилия [12, р. 90]. В это время еще была возможность нанять вооруженную охрану из неменнонитов. Деньги для этого, особенно в Молочанских и Хортицких колониях имелись, и немалые, и уберечь тем самым сообщество от обвинения в вероотступничестве.

Стратегическую ошибку меннониты совершили с приходом австро-немецких войск, когда попросили у них защиты ${ }^{4}$. Следующие 8 месяцев стали бедствием для украинских крестьян и оттепелью, даже праздником для меннонитов. Немецкие офицеры привнесли новизну в колонии: музыку, танцы, военный оркестр, прогерманскую агитацию. В богатом Гальбштадте «патриотические» речи легли на благодатную почву, особенно среди молодежи коммерческого училища, в котором большинство составляли сыновья богатых предпринимателей, землевладельцев и старшин [6]. Местный муниципалитет совместно с немцами-военнослужащими в кайзеровской форме провели «фестиваль», главными номерами которого были марш-музыка, футбол, танцы, пиво (рис. 1). Все это способствовало подъему энтузиазма и воинственных настроений у молодежи [12, p. 111]. Социальные последствия такого «братания» обеспокоили многих меннонитов. Д. Эпп пишет: «бестактное знакомство с оккупационной армией посредством фестиваля произвело моральный эффект на молодежь и явилось фактором, способствующим появлению Selbstschutz (корпуса самообороны)» $[12$, р. 111]. Выдержки из дневников подтверждают эту точку зрения: «Это деморализовало наше общество... Молодежь вошла в контакт с внешним миром, что очень вредно... женская гордость утеряна в этом поколении... приобщили нашу молодежь к пиву... позор падает на всех» [13, p. $27 ; 23$, р. 50, 51]. Кроме того, нашлось немало желающих принять германское гражданство $[13$, p. 44, 47].

Конференция в Лихтенау стала очередным этапом перерождения меннонитов и примером лицемерия их лидеров. Отныне они потеряли право налагать дисциплинарное церковное отлучение за агитацию и действия милитаристского характера. Не осудив самооборону, конференция позволила ее сторонникам открыто создавать военизированные структуры. Активисты Selbstschutz не приняли во внимание убеждения тех, кто отстаивал позицию воздержания от оружия и своей активностью подавляли их мнение, а впоследствии часто преследовали сторонников мира. Так, например, Яков Дик был арестован в Тигервейде [9]; из колонии Айхенфельд выгнали сторонников пацифизма. В других колониях разногласия между приверженцами самообороны и последователями веры выражались в спорах либо в отчуждении. Проявлялись и двоякие чувства к происходящим событиям. Так, Анна Берг в своем дневнике сетует на отступление от былых моральных устоев: «...Что сказали бы на это (организацию вооруженных отрядов) наши предки?..

\footnotetext{
${ }^{4}$ Офищеры оккупационных войск охотнее помогали колонистам, общаясь с ними на немецком и признавая / видя в них этнических немцев, чем землевладельцам других национальностей. Это обстоятельство крестьяне и махновцы восприняли как подтверждение родства меннонитов и недавнего врага по кровопролитной войне, нынче продолжающего грабить села украинцев.
} 


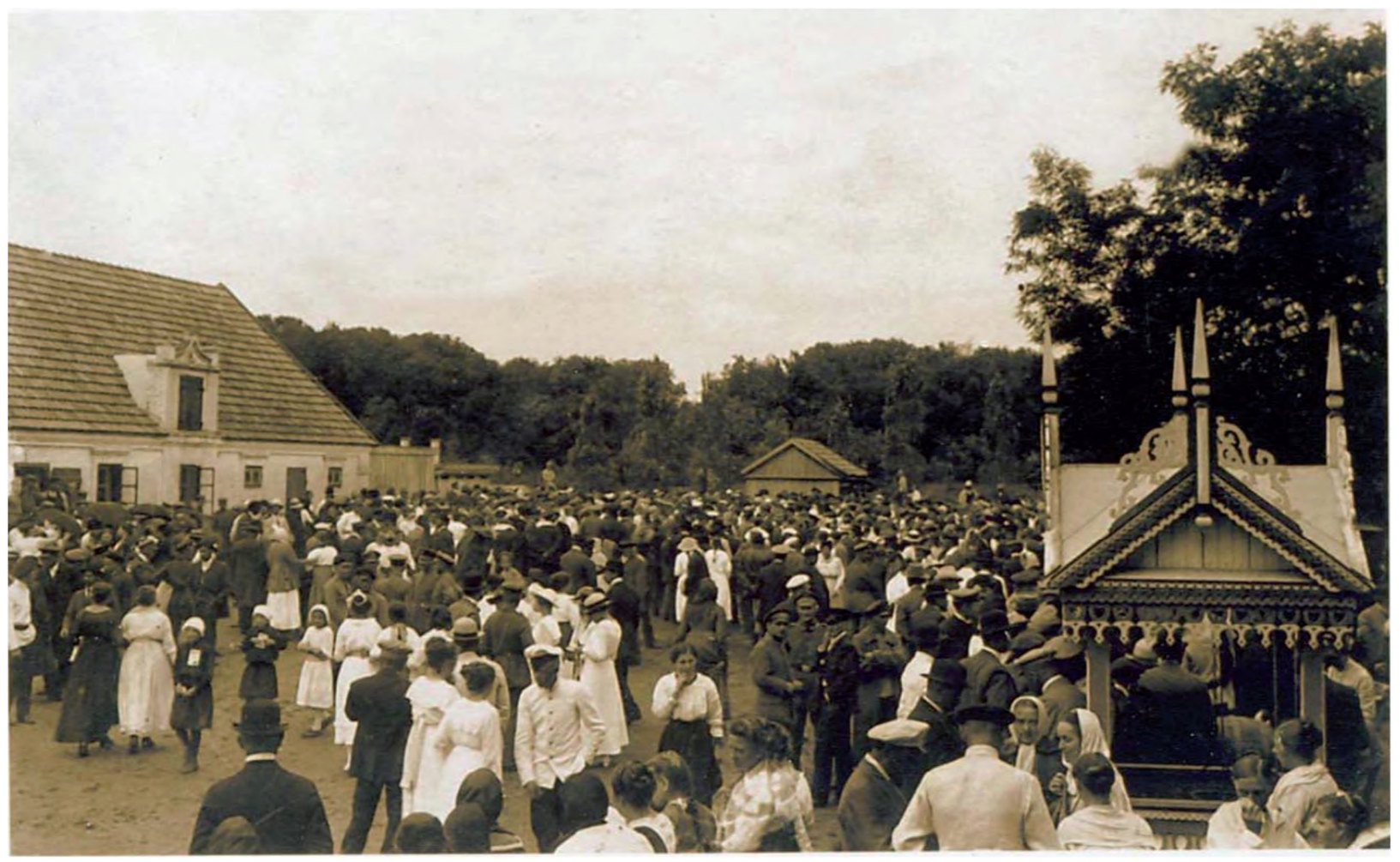

Рис. 1. Фестиваль в колонии Орлово с участием немецких военнослужащих.

Разве пацифизм не является основной целью христианства? Но все это теперь лишш мечта. Наш пацифизм развалился и теперь нет пути назад». В то же время она гордится, что меннониты, ранее никогда не воевавшие, оказались мужественными в деле запциты семьи и достоинства $[13$, p. 34,43$]$. Этот внутриобщинный конфликт увеличивал опасность для нейтрально настроенньгх и убежденньгх пацифистов, т. к. махновцы при нападении на поселения, не разбираясь в их взглядах, расправлялись со всеми мужчинами. Так было в Блюменорте и в Заградовских колониях в ноябре 1919 г., где были убиты стойкие приверженщы веры - учитель и проповедник Петер IШмидт [21, p. 14], учитель Генрих Нойфельд и другие. Убийства и насилие над невиновными порождало чувство мести в умах неустойұивых в вере, толкая их в ряды Selbstschutz.

Стоит отметить, что заинтересованными в создании отрядов самообороны являлись, прежде всего, крупные землевладельцы, которьх поддерживало большинство старшин. Для привлечения в боевые отряды молодых людей был создан особый фонд (наполнялся в виде налога, 2/3 которого составлял налог на стоимость имущества и $1 / 3$ подушный [12, p. 103]), из которого участникам Selbstschuts выплачивали по 250 рублей. Первые отряды были сформированы в Гапббштадте, Ладеко- пе, Мунтау, Тигенхаге (Молочанский округ) и Тиге в Заградовских колониях.

Наиболее масштабно Selbstschutz организовывался в Молочанских колониях, гдебыл избран комитет, поставивший целью сформировать боеспособный полк с налаженной инфраструктурой, включающий птаб, два подразделения связи (телефонной и мобильного транспорта), пехоту, кавалерию, пулеметные и разведывательные подразделения, артиллерию с полевыми орудиями, фортификационную роту, медипинский корпус и трибунал. В его состав должны были входить 20 пехотнљг рот (из них 7 рот немецких колонистов) численностью до 2700 человек и 5 отрядов кавалерии (300 человек). Одним из первых было организовано подразделение, составленное из слушателей Гальбштадского коммердеского училища. Формирование отряда происходило под гимн Германии, который 18-20-летние студенты пели с большим энтузиазмом $[12$, p. 124]. Руководителями Selbstschutz были немецкие офицеры. Такой масштаб и широкое представительство (совместно с немепкими колонистами) уже само по себе демонстрировало, что цели Selbstschutz с самого начала его организации вьходили за рамки узкой самообороны меннонитских поселений и носили потенщиально агрессивный характер. Бои против махновцев за немецкую колонию Блюменталь и другие немецкие поселения, в 
которых главную силу представляли меннониты из Гальбштадта, подтвердили это.

В конще 1918 г. и особенно в 1919 г. многие меннониты-землевладельцы из небольших поселений и хуторов, преследуя цель обезопасить себя и свои семьи от нападений бандитов, стали переселяться в крупные колонии, сдавая землю в аренду безземельным соплеменникам на льготных условиях или уступая в пользование (обычно родственникам или знакомым) без арендной платы. Это позволило, во-первых, оставлять хозяйства под присмотром, что увеличивало вероятность сохранности собственности (так как махновцы относились к беднякам достаточно лояльно), во-вторьх, снизить социальную напряженность внутри сообщества, предоставляя бедным возможность обеспечивать свои семьи. Однако конфликт между имущими и безземельными продолжал тлеть и был лишш пригашен. Нужно отметить, что в революционные и послереволюционные годы регресс в социальных отношениях внутри общин, как и в вопросах взаимопомоши, продолжался и нарастал. Так, Г. Нойфельд в дневнике отмечал, что учителя преклонного возраста (Хортицкая община в 1919 г.) были лишены пенсионного обеспечения и, не имея земли и запасов на зиму, голодали $[17$, р. 59]. То же происходило в Заградовских колониях, где многодетная семья погибшего учителя-проповедника Генриха Нойфельда была лишена пенсии [18, p. 39]. Наглядно свидетельствует об утрате ответственности за каждого факт, приведенный Д. Нойфельдом: когда при массовом бегстве меннонитов из разгромленной махновцами колонии никто из обгоняющих на колясках и телегах не захотел остановиться и подвезти семью учителя И. Берга или его самого, бредущего под осенним холодным дождем с больным сыном на ру$\operatorname{\kappa ax}[18$, p. 28]. Американский меннонит Давид Хофер посетивший колонии в 1920-х гт., отмечал, что «люди ожесточены и несправедливы к собственным братьям. Духовная и моральная жизнь полностью разрушены» [7]. Во многих колониях малоправные, обиженные социальной несправедливостью и старшинами, принявшие классовые идеи или превратившиеся в маргиналов меннониты становились под знамена
Красной или Повстандеской армии Махно. И таких было немало 5 . По оценке И. Раймера, попасть в руки служивших у Махно меннонитовренегатов было особенно опасно. Они хорошо знали, кто служит в отрядах самообороны, доносили на них, порой чинили расправу сами [7].

Сообщество, которое в прошлые времена быстро реагировало на угрозу миграцией, на этот раз, в период бандитизма и разбоя, не проявило обырной мобильности. Это произошло, по всей вероятности, из-за того, что, утратив духовную основу и не доверяя прежним лидерам, многие меннониты-общинники стали ориентироваться на светских лидеров - крупнтх землевладельцев и предпринимателей, которые чаще имели низкий уровень сощиальной ответственности и, не желая расстаться с личной недвижимостью (продать ее в тех условиях было невозможно), оказались плохими руководителями, политиками и провидцами. Не просчитав возможных последствий, они приняли ряд фатально ошибочных решений. Сначала, весной 1918 г., полагал, что приход немецких войск позволит установить порядок, радушно приветствовали оккупационные войска и просили у них запиты. Затем стали одними из инипиаторов и финансировали самооборону, привлекая в ее ряды малоимущих. И, наконец, сделали ставку на «победное» наступление Деникина. В результате время для организации масшттабного исхода ${ }^{6}$ было упущено. Уехали, понимая, что элита не хочет эмиграшии, единицы ${ }^{7}$

Остальные жители колоний, «попав под прицел» махновцев, которые не простили сообществу Selbstschutz и добровольцев в Белой apмии, вынуждены были выживать и надеяться на лучшшие времена. Только несколько конгрегаций, строго придерживавшихся пацифистских взглядов, не стали жертвами мести. Десятки колоний были уничтожены или разорены. Из трагедии этих поселений меннониты не сделали должных выводов и публичных шагов для во3врата к приншипу непротивления. К 1923 г. поляризация в меннонитском сообществе оказалась настолько радикальной, что в Канаду в течение 1923-1926 гт. эмигрировала только 21 тысяча ее членов. Однако и они по моральноэтическим принщипам значительно отличались от меннонитов-эмигрантов первой волны ${ }^{8}$.

\footnotetext{
${ }^{5}$ Некоторые колонисты, сторонники большевиков, из Лихтенау, Николайталя, Гнаденхайма и других меннонитских поселений в 1918 г. были казнены оккупантами [7].

${ }^{6}$ Идея об эмиграции имела широкое распространение после ухода австро-немецких войск [13, p. 35$]$.

${ }^{7}$ Например, из Розенфельда (Борозенковские колонии) в этот период выехала, оставив две мельницы, технику и хозяйство, лишь одна семья.

${ }^{8}$ В годы Советской власти, оставшиеся на Украине, также не смогли найти согласие, в том числе в отношении происходящих в стране перемен. Одни приветствовали строительство социалистических отношений, другие стоически переживали трудные времена, третьи стали врагами Советской власти и государства, о чем свидетельствует факт добровольного вступления членов общин из Молочанского округа и Кронау в части СС во время Второй мировой войны.
} 
Завершающий аккорд в цепи отступлений от канонических и моральных принципов «сообщества воплощавшего идеалы Царства Божьего» - отказ от пацифизма, был следствием более ранних ошибочных действий их лидеров. Во-первых, на этапе модернизации экономических отношений в сообществе не было изменено внутриобщинное налогообложение в пользу справедливого социального распределения за счет быстро растущих доходов предпринимателей и латифундистов, во-вторых, ограничение прав безземельных разрушало демократические основы группы. Это способствовало подрыву единства сообщества. Гордыня и отступление от Божьего завета вели к высокомерию в общении и производственных отноштениях со славянским населением, что накаляло обстановку вокруг колоний. И, наконец, сотрудничество с оккупационными войсками, вместо молитвы, обращенной к Богу, привело в итоге к конфронтации с народными массами и кровопролитию.

Заключение. Меннониты в России за короткий период времени от начала реформ $1860-70-\mathrm{x}$ годов до начала $\mathrm{XX}$ в. прошли путь от закрытого религиозного до открытого, но ослабленного духовно, прагматично направленного сообщества. Это, при оставшемся на прежнем уровне дореформенном внутриобщинном налогообложении (для общественных нужд и социального обеспечения), привело к существенному имущественному расслоению, потере былого согласия в сообществе и, в итоге, к его разложению. За указанный и последующий за ним период Первой мировой войны меннониты, изменив прежней идеологии, последовательно отступились от принципов: неучастия во властных структурах, отказа от клятвы верности принявшему их государству, несодействия войне путем производства военной техники и боеприпасов, а в период гражданской войны - от фундаментального принципа своей веры - пацифизма. Все это, в совокупности с отступлением от присущих им ранее морально-этических норм, ослаблением или полной ликвидацией социальной ответственности за своих членов, позволяет поставить вопрос: остались ли российско-украинские меннониты меннонитами в смысле этно-религиозного сообщества или трансформировались в категорию населения, неотличимую от немчев и называемую меннонитами только в силу инерчионного мышления.

\section{Библиографические ссылки}

1. Безносов О. За «Неimatland». Збройні формування німецьких колоністів та менонітів Півдня України. Війсъково-історичний альманах. 2011. № 1 (22).

2. Венгер Н. В. «Неличная история»: меннонитская община Александровска в переломный год Украинской революции. Сучасні дослідження з німеџькой ісmopit. Д., 2019. С. 62-74.

3. Венгер Н. В. Меннонитское предпринимательство в условиях модернизации Юга России: между конгрегацией, кланом и российским обществом. Д., 2009. С. 399.

4. Дик И. О секуляризации и трансформации идентичности российских меннонитов. Boпросы германской истории: сб. науч. ст. Д., 2017. С. 49-53.

5. Екатеринославский адрес-календарь. 1915 год. Екатеринослав: Изд. губернской тип., 1915, 541 с.

6. Кандидов Б. П. Религиозная контрреволюция 1918-1920 гт. и интервенция. М.: Безбожник, 1930.

7. Райнер Иоханнес. Евангелизация перед лишом смерти : Яков Дик и Русская палаточная миссия : пер. с нем. Харзевинкель: Bild \& Medien GmbH; СПб., 2002. 162 с.

8. Ремпель Леонард. Трагедия колонии Заградовка. Украина. 1919 год. URL http://www.proza. ru/2017/04/15/2183 (дата обращения 30.09.2020).

9. Салов-Астахов Н. Палаточная миссия. Ирпенская Библейская семинария. $69 \mathrm{c}$.

10. Трубецкой С. Е. Минувшее. М., 1991. 340 с.

11. Canadian Mennonite World War I Resolution. URL http://replica.palni.edu/cdm/compoundobject/ collection/gop-plow/id/2218/rec/15 (дата обращения 10.11.2020).
12. Chipman J. The Mennonite Selbstschutz in the Ukraine. A theses, 1998. URL https://mspace.lib.umanitoba. $\mathrm{ca} / \mathrm{xmlui} / \mathrm{handle} / 1993 / 3535$ (дата обращения 09.08.2020).

13. Diary of Anna Baerg. / trans. and edited by Gerald Peters. Winnipeg, 1985. $158 \mathrm{p}$.

14. Klippenstein L. The Selbstschuts: a Mennonite army in Ukraine. Bопросы германской истории: сб. науч. ст. Д., 2007. С. 175-205.

15. Kroeger Arthur. Hard Passage: A Mennonite Family's Long Journey from Russia to Canada. University of Alberta, 2007. $269 \mathrm{p}$.

16. Letters of a Mennonite Couple: Nicolai and Katharina Rempel. Russia: War and Revolution 1914-1917. Introduced and edited by Teodor Rempel. Translated by Teodor Rempel with Agatha Klassen. Fresno, CA: Center for Mennonite Brethren Studies, 2014. 246 p.

17. Neufeld D. Ein Tagebuch aus dem Reiche des Totentanzes. Emden Selbstverlag des Verfassers, 1921. 88 p.

18. Neufeld D. Mennonitentum in der Ukraine. Schicksalsgeschichte Sagradowkas, 1922.40 p.

19. Neutatz D. Lāndliche Unternehmer im Schwarzmeergebeit Die sudukrainische Landmaschinenindustrie voe dem Ersten Weltkried. «...das einzige Land in Europa, das eine grobe Zukunf vor sich hat». Essen, 1998. S. 541-574.

20. Reimer A1. Sanitâtsdienst and Selbstschutz: Russian-Mennonite Nonresistance in World War I and its Aftermath. Journal of Mennonite Studies. Winnipeg, 1993. Vol. II. P. 135-148.

21. Teows J. No songs were sung at the gravesite. The Blumenort (Russia) Massacre (November, 1919). Journal of Mennonite Studies. Winnipeg, 1995. Vol. 13. P. 51-70. 
22. Thy Kingdom Come: The Diary of Johann J. Nickel of Rosenhof: a Record of Violence and Faith During the Russian Civil War. Midwest Litho Limited, 1978. $104 \mathrm{p}$.

23. Troubles and triumphs: 1914-1924; excerpts from the diary of Peter J. Dyck, Ladekopp, Molotschna Colony, Ukraine. Manitoba, 1981.
24. Wedel C. H. Geschichte der Mennoniten. Гocyдарственный архив Одесской области. Фонд 89. Оп. 1. Дело 3598. Лист 12-13.

25. Werner H. An Array of Contradictions: Mennonite Expressions of Nationalisin in Imperial Russia during World War I. Bonросы германской истории: сб. науч. ст. Д., 2015. С. 130-145.

\section{References}

1. Beznosov O. For "Heimatland". Broken formulation of German colonies and menonites of the Holy Day of Ukraine (1918-1921). Viy'skovo-historical almanac. 2011. No. 1 (22). P. 7-23 (in Russian).

2. Venger N.V. „Non-personal history“: the Mennonite community of Aleksandrovsk in the crucial year of the Ukrainian revolution. Suchasni doslidzhennya z nimetskoj istorij. 2019. P. 62-73 (m Russian).

3. Venger N.V. Mennonite Entrepreneurship in the Context of Modernization of the South of Russia: Between Congregation, Clan and Russian Society (1789-1920). D., 2009. 696 p. (in Russian).

4. Dick I. On the secularization and transformation of the identity of the Russian Mennonites. Questions of German history: collection of scientific articles. D., 2017. P. 49-53. (in Russian).

5. Yekaterinoslav address-calendar. 1915 year. Ekaterinoslav: Ed. Provincial type., 1915. 541 p. (in Russian).

6. Kandidov B. P. Religious counter-revolution 1918 1920 and intervention. M., 1930. (in Russian).

7. Rainer Johannes. Evangelism in the Face of Death: Jacob Dick and the Russian Tent Mission: trans. with him. Harsewinkel: Bild \& Medien GmbH; SPb.: Christian. Society "Bible for All", 2002. 162 p. (in Russian).

8. Rempel Leonard. The tragedy of the Zagradovka colony. Ukraine. 1919 file:///C:/Users/User/Documents/ ViberDownloads/0-02-0a-11048998f0afb99faaaa7cc56cbf 2fe558f36092116a9064f4f0697cfd2d748b_65b183d6.jpgyear. Access mode: http://www.proza.ru/2017/04/15/2183 (date of treatment 09/30/2020). (in Russian).

9. Salov-Astakhov N. Tent mission. Publisher: Irpen Biblical Seininary. 69 p. (in Russian).

10. Trubetskoy S. E. The Past. M.: DEM, 1991. 340 p. (in Russian).

11. Canadian Mennonite World War I Resolution. Access mode: http://replica.palni.edu/cdm/compoundobject/collection/gop-plow/id/2218/rec/15 (date accessed 10.11.2020)

12. Chipınan J. The Mennonite Selbstschutz in the Ukraine: 1918-1919. A theses, 1998. Access mode: https:// inspace.lib.umanitoba.ca/xmlui/handle/1993/3535 (date of access 08/09/2020).
13. Diary of Anna Baerg. 1916-1924 / trans. and edited by Gerald Peters. Winnipeg, 1985. 158 p.

14. Klippenstein L. The Selbstschuts: a Mennonite army in Ukraine 1918-1919. Questions of German history: collection of scientific articles. D., 2007. P. 175-205.

15. Kroeger Arthur. Hard Passage: A Mennonite Family's Long Journey from Russia to Canada. University of Alberta, 2007. 269 pp.

16. Letters of a Mennonite Couple: Nicolai and Katharina Rempel. Russia: War and Revolution 1914 1917. Introduced and edited by Teodor Rempel. Translated by Teodor Rempel with Agatha Klassen. Fresno, CA: Center for Mennonite Brethren Studies, 2014. 246 p.

17. Neufeld D. Ein Tagebuch aus dem Reiche des Totentanzes. Emden Selbstverlag des Verfassers, 1921. 88 p.

18. Neufeld D. Mennonitentum in der Ukraine. Schicksalsgeschichte Sagradowkas, 1922. 40 p.

19. Neutatz D. Ländliche Unternehmer im Schwarzmeergebeit Die sudukrainische Landmaschinenindustrie voe dem Ersten Weltkried. «...das einzige Land in Europa, das eine grobe Zukunf vor sich hat». Essen: Klartext Verlag, 1998. S. 541-574.

20. Reimer Al. Sanitätsdienst and Selbstschutz: RussianMennonite Nonresistance in World War I and its Aftermath. Journal of Mennonite Studies. Vol. II. 1993. P. 135-148.

21. Teows J. No songs were sung at the gravesite. The Blumenort (Russia) Massacre (November 10-12, 1919). Journal of Mennonite Studies. Vol. 13. 1995. P. 51-70.

22. Thy Kingdom Come: The Diary of Johann J. Nickel of Rosenhof, 1918-1919: a Record of Violence and Faith During the Russian Civil War. Midwest Litho Limited, 1978. $104 \mathrm{p}$.

23. Troubles and triumphs: 1914-1924; excerpts froin the diary of Peter J. Dyck, Ladekopp, Molotschna Colony, Ukraine. Manitoba, 1981.

24. Wedel C. H. Geschichte der Mennoniten. Vol. 2. P. 140. State archive of the Odessa region. Fund 89 . Inventory 1. File 3598. Pp. 12-13.

25. Werner N. An Array of Contradictions: Mennonite Expressions of Nationalism in Imperial Russia during World War I. Questions of German history: collection of scientific articles. D., 2015. P. 130-145. 